Rule prevails, however, there remains a concern that the framework formulated for Rust $v$. Sullivan would still provide a vehicle for similar rulings in other cases.

Although a number of leading constitutional lawyers indicated that the decision was narrowly drawn and probably not applicable to other content-based activities supported with federal funds, some key officials in both the Department of Justice and the Office of Management and Budget are believed to view the ruling as an opportunity to assert government prerogative for contentbased restrictions in many or all cases when the government is funding activities of organizations and individuals outside of the government.

Constitutional lawyer James F. Fitzpatrick and his colleagues $\mathrm{L}$. Hope O'Keefe, and Steven M. Marks of the Washington firm of Arnold \& Porter produced "Constitutionality of Content-Based Restrictions on Federal Funding of the Arts After Rust $v$. Sullivan" which was released as an extended memorandum on June 8. Quoting from Mr. Rehnquist, "This is not to suggest that funding by the Government . . . is invariably sufficient to justify government control over the content of expression," Mr. Fitzpatrick and his colleagues state: "Nothing in Rust justifies government control over the content of federally funded arts and humanities. Rust leaves intact the fundamental constitutional principle that the Government may not condition a subsidy on the waiver of the First Amendment right to freedom of expression and may not use the carrot of government benefits as a stick to suppress 'dangerous ideas' "' and go on to offer the following four arguments for their position:

"First, the Supreme Court considered that Rust was essentially an abortion case. The Court concluded that restrictions on funding of abortion counselling were simply a logical outgrowth of restrictions on abortion funding which have long been held constitutional. In contrast, arts content restrictions are not mere ancillary to a government refusal to fund a non-speech activity. Rather, they are a direct restriction of constitutionally protected speech. Court after court has held that speech in the areas sought to be regulated-nonobscene 'indecent' speech, 'blasphemy,' and 'denigration'-is constitutionally protected.

"Second, and most critically, Rust reaffirmed the long line of Supreme Court precedents that forbid the Government to condition subsidies on adherence to unconstitutionally vague and overbroad content restrictions.

"Third, the counselling restrictions in Rust were an integrated and con- sidered part of a congressionally designed program. Far from being consistent with the federal arts funding program, content restrictions on art are antithetical to Congress' established mandate to the NEA to further creative artistic activity.

"Finally, arts funding content restrictions, unlike Title $X$ regulations, impose speech restrictions upon individual and institutional recipients, not solely upon a 'project' and accordingly are not 'coupled with the freedom of the fund recipients to speak outside the scope of the Government-funded project.'

"Thus, the Court's validation of restrictions on abortion in Rust simply cannot be exported wholesale to rationalize and justify the imposition of content restrictions on arts funding."

Editor's Note: APSA is a member of the National Humanities Alliance and Executive Director Catherine Rudder sits on its board. Relying on the Arnold \& Porter memorandum quoted in part in the last six paragraphs of this report, the NHA has decided to take no action and to make no public statements on Rust v. Sullivan. If you have thoughts on this matter that you would like to have communicated to $N H A$, please contact Catherine Rudder, APSA, 1527 New Hampshire Ave., NW, Washington, DC 20036, or Fax (202) 483-2657.

\title{
Women Make Better Grades Than Men
}

\begin{abstract}
Although their educational aspirations tended to be lower than those of men, women in the 1972 high school graduating class pursued postsecondary education at the same rate as and finished college faster than their male counterparts, a study from the Education Department shows.

Women also received more postsecondary scholarships, earned higher grade point averages regardless of their field of study, and achieved higher grades in both statistics and calculus courses, the report says.
\end{abstract}

The report, Women at Thirtysomething: Paradoxes of Attainment, traces the educational and career paths of women who graduated from high school in 1972 through their 32nd year. The study found that, despite the women's superior educational performance, they were more often unemployed between the ages of 25 and 32, and achieved income levels equal to men in only seven of 33 occupations.

Nevertheless, the study says, the women more frequently worked in fields that were relevant to their courses of study and tended to take a more positive attitude toward job conditions and learning new skills.

The report is available for $\$ 4.25$ from the Government Printing Office, North Capitol and H Sts., N.W., Washington, DC 20401; (202) 783-3238. The stock number is 065-000-00-451-8.

Reprinted from: American Council on Education's Higher Education and National Affairs. 